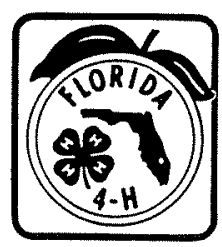

\title{
FLORIDA 4-H HORSE MEMBER ADVANCEMENT PROGRAM LEVEL II
}

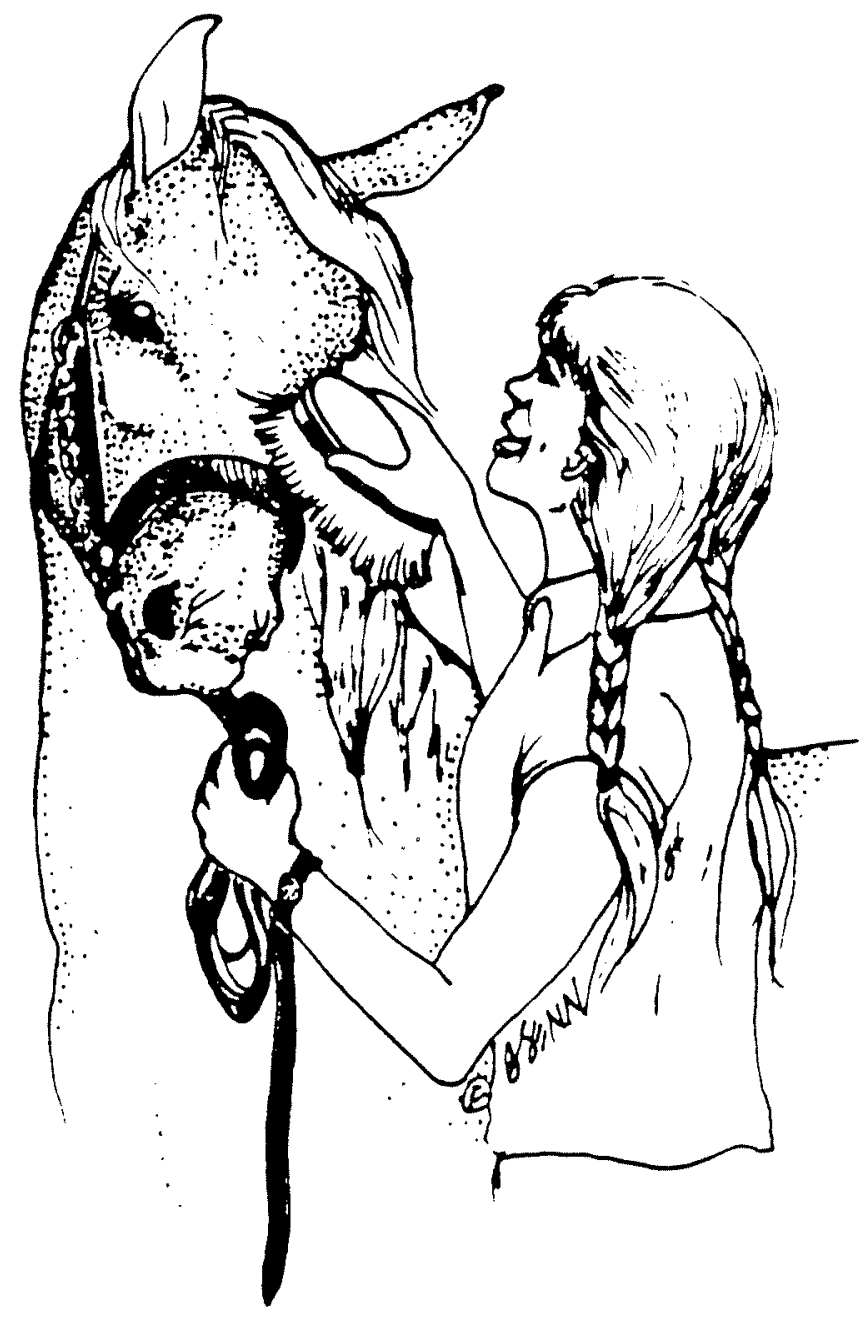

Level II of The 4-H Horse Member

Advancement Program will --

* help you develop an understanding of horses and horse care.

* help you learn the basic skills of riding and handling horses.

* provide goals for learning.

* make your 4-H horse experience more interesting and more fun.

* let you progress at your own speed, but challenge you to keep working to become a better horseman and 4-H member.

The Novice Horseman Level is the second of four 4-H Horse Advancement Levels. No time limits are set and you are encouraged to advance through the tests and levels at your own speed.

Novice Level requirements are based on four areas -- experience, knowledge, mounted and dismounted abilities. You will be evaluated in each area by your 4-H Club leader or trained inspector. You are not in competition with other club members.

For Novice Level activities, older, gentle horses or ponies are best. Horses that perform natural gaits (walk, trot and canter) are preferable, but exceptions will be made in some riding tests if your horse can't trot.

Name

Florida Cooperative Extension Service/Institute of Food and Agricultural Sciences/University of Florida/J.T. Woeste, Dean 
Section 1 - Experience

A. Horse Care

Has been responsible for primary care (including feeding, watering, grooming, stall cleaning and exercise) of the project horse for days (minimum 90 days)。

Signed Parent Leader

B. Riding Record (Minimum of 60 hours)

\begin{tabular}{|l|l|l|}
\hline \multicolumn{1}{|c|}{ MONTH } & TYPE OF RIDING & HOURS \\
\hline September & & \\
\hline October & & \\
\hline November & & \\
\hline December & & \\
\hline January & & \\
\hline February & & \\
\hline March & & \\
\hline April & Total Hours & \\
\hline May & & \\
\hline June & & \\
\hline July & & \\
\hline August & & \\
\hline
\end{tabular}

C. Events Participated In (Minimum of any three of the following at any level -- horse judging contest; show; horsemanship school or clinic; trail ride; AHSA or approved breed show; fitting \& showmanship class; hunt; horse bowl cont4st; tour of a horse farm or stable).

\begin{tabular}{|l|c|c|}
\hline DATE & EVENT & LOCATION \\
\hline & & \\
\hline & & \\
\hline & & \\
\hline & & \\
\hline & & \\
\hline
\end{tabular}


D. Club Participation

I. Number of meetings attended (minimum 6)

2. Present a satisfactory demonstration on horse care at a 4-H meeting date topic signed (leader)

E. Field or Educational Experience (Must do at least two of the following)
Program
Name
Date

See a Horse Movie

See a Slide set about horses

Read a horse magazine

Visit a horse farm or stable

\section{Section 2 - Knowledge}

A. Describe what can happen if a horse gains access to an unlimited grain supply.

B. Describe what can happen if a hot horse is immediately given all of the water he can drink.

C. Identify moldy and dusty feed and discuss the dangers of feeding this to a horse. 
D. Briefly discuss basic safety precautions to prevent injury to horse and to handler or rider. (Include safety headgear)

E. Briefly discuss "suitability of horse to rider."

F. Visit a place with a large group of horses (farm or show) and: Identify five different colors of horse

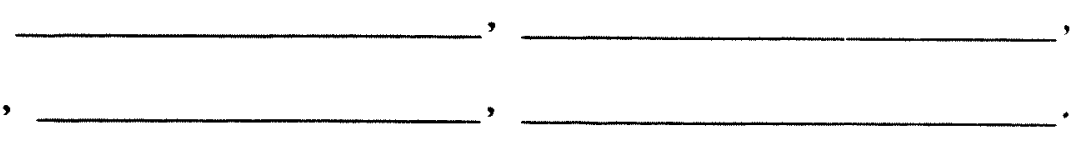

Identify (recognize) a mare, stallion, colt, filly, and gelding.

Date/s identified 
G. Draw or trace front views of four horse heads and draw in and label face markings - star, stripe, blaze and bald.

H. Review and follow thirteen general feeding and management guidelines:

1. Exercise horses regularly.

2. Make sure that parasite control is adequate.

3. Examine teeth regularly.

4. Feed at regular times.

5. Avoid moldy and dusty feed.

6. Keep the feed manger clean.

7. Give small, frequent feedings.

8. Feed by weight, not volume.

9. Make changes in types and amounts of feed gradually.

10. Do not overfeed. Do not underfeed.

11. Make sure that water is frequently available, fresh and clean.

13. Keep stall and paddock areas clean and safe. 
I. Take a feed tag from a bag of horse feed, review and discuss with a knowledgeable person and reproduce (draw) the tag below:

J. Briefly study then assign the following feed items to the appropriate categories - soybean oil meal, corn, oats, alfalfa hay, bermuda grass hay.

$\underline{\text { Energy }}$
Protein

Forage 
Section 3 -Dismounted Abilities: Give the date on which you properly demonstrated the following dismounted abilities to a designated fnspector or leader.

Date

Leader

1. Muck out and bed down a stall

2. Put on and adjust a halter

3. Put on and adjust a bridle

4. Clean tack

5. Care for a horse after a demanding ride

6. Properly tie a horse (a rail, a tree and a ring)

7. Prepare a horse for a showmanship class (braiding not required)

8. Demonstrate how to show a horse in a fitting and showmanship class

9. Recognize good quality and poor quality pasture

10. Identify good hay quality

11. Demonstrate and discuss safety in working with horses

Section 4 - Mounted Abilities: Give the date on which you properly demonstrated the following mounted abilities to a designated inspector or leader: (Five items may be designated as optional with substitutes listed and done at the bottom of the list). Additional tests may also be listed at the end of the list.

Date

Leader

1. Move from a halt to a walk and from a walk to a halt

2. Walk in a small circle (both directions)

3. At the walk, turn right and turn left

4. Walk in a straight line, halt, turn

right about and return in a straight line, halt, turn left about and return in a straight line, halt

5. Trot (around a ring-both directions) 
Section 4 (Continued)

Date

Leader

6. Take up the trot from the halt and the walk - and return from the trot to the walk and to the halt

7. At the trot, turn right and turn left

8. Trot in a straight line, turn right about and return in a straight line and turn left about and go in a straight line, halt

9. Trot a small circle - both directions

10. Walk and trot a figure eight

11. Canter left lead around a ring

12. Canter right lead around a ring

13. Back 6 steps and halt

14. Stand still 10 seconds

15. Lead over a dropped rail

16.

17.

18.

19.

20 .

21.

22 .

23.

24.

25 . 


\section{PERSONAL DEVELOPMENT/COMMUNITY PRIDE OPTIONS}

1. Lead the Pledge of Allegiance or 4-H pledge at a 4-H meeting.

2. Lead a song or game at a 4-H meeting.

3. Preside at a 4-H project or club meeting.

4. Write a news story for a local paper.

5. Arrange for a film to be shown at your club meeting.

6. Participate in a radio or television program.

7. Present a demonstration or illustrateditalk to a group other than your 4-H group.

8. Serve as host for a $4-H$ meeting. See that everyone is welcomed and made comfortable.

9. Participate in a community service project.

10. Participate in a community pride project.

11. Prepale a display (pictures, clippings, objects) that can be educational or helpful in stressing: clean air, clean land, or clean water; conserving natural resources; conserving energy; or practicing safety.

12. Serve as chair of a club committee.

13. Participate in a horse judging or identification contest.

14. Serve as a junior leader for a $4-\mathrm{H}$ Horse group.

15. Make arrangements for a tour by your project group.

16. Attend a 4-H camp.

17. Serve as a camp counselor.

18. Attend a district or state animal science workshop.

(Select three or more options)

Opt ion Number

$$
\begin{array}{ll}
\text { Date } & \text { Approved } \\
\text { Passed } & \text { by }
\end{array}
$$

19. Serve as clerk, show chairperson, or apprentice judge at a $4-\mathrm{H}$ show.

20. Develop and exhibit a science display which is related to horses.

21. Explore a career associated with horses and report on that career to your project group or community club.

22. Secure a speaker to talk at one of your project meetings.

23. Plan a fun activity for your club or project group that is separate from a regular meeting.

24. Become a junior leader for a $4-\mathrm{H}$ Horse group.

25. Obtain three or more new horse members for your club.

26. Help conduct a horse show.

27. Help organize and conduct an educational tour or demonstration.

28. Help organize and conduct a field day or judging event.

29. Help a leader work with a younger member.

30. Demonstrate riding aids to your club.

31. Help organize, train, and participate in a mounted drill team.

32. Help organize and conduct a trail ride.

33. Serve as an apprentice judge at a 4-H Horse Show.

34. Serve as a counselor to younger $4-\mathrm{H}$ members.

35. Help organize a Horse Bowl.

36. Help organize a horse farm tour.

37. Organize and conduct a $4-\mathrm{H}$ judging contest.

$\therefore$ Develop your own option with your leader's approval. (This may be used more than once.)

38.

39.

40. 
This is to certify that is qualified and has completed all of the Novice Horseman Requirements for Level. II of the 4-H Horse Advancement Program. 
1. This document is 4HSWG04 of the Florida 4-H Youth Development Program, Florida Cooperative Extension Service, Institute of Food and Agricultural Sciences, University of Florida. Printed Jan., 1989; Reviewed June 2002. Please visit the EDIS website at http://edis.ifas.ufl.edu.

2. Dr. E.L. Johnson and Dr. R.L. Horton Publication contact: Nancy Johnson, 4-H Publication Coordinator, Department of Family, Youth and Community Sciences, Cooperative Extension Service, Institute of Food and Agricultural Sciences, University of Florida, Gainesville 32611.

COOPERATIVE EXTENSION SERVICE, UNIVERSITY OF FLORIDA, INSTITUTE OF FOOD AND AGRICULTURAL SCIENCES, Christine Taylor Waddill, Director, in cooperation with the United States Department of Agriculture, publishes this information to further the purpose of the May 8 and June 30,1914 Acts of Congress; and is authorized to provide research, educational information and other services only to individuals and institutions that function without regard to race, color, age, sex, handicap or national origin. The information in this publication is available in alternate formats. Single copies of extension publications (excluding 4- $\mathrm{H}$ and youth publications) are available free to Florida residents from county extension offices. Information on copies for out-of-state purchase is available from Publications Distribution Center, University of Florida, PO Box 110011, Gainesville, FL 32611-0011. 